\title{
The Contribution of a Longitudinal Approach to Family Solidarity Surveys: Reflections on the Temporality of Exchanges
}

\author{
Marianne Kempeneers \\ Université de Montréal \\ Montréal, Québec, Canada \\ marianne.kempeneers@umontreal.ca
}

\author{
Éva Lelièvre \\ Catherine Bonvalet \\ INED, Paris, France
}

\begin{abstract}
The topic of intergenerational family solidarity which is the focus of unprecedented interest for both policy makers and researchers, has promoted numerous studies centered on the bonds that unite generations and the dynamics of family solidarity through time. The notion of time is thus central to this field of research. In this paper, after an overview of various longitudinal perspectives adopted in family solidarity surveys; we identify the major methodological challenges raised by the dynamics of "family solidarity". Three distinct temporal aspects must be considered: historical time, which applies to the maintenance of solidarity over time despite structural change in both families and society; generational time implied by the primacy of intergenerational exchanges; and finally, biographical time, which refers to the calendar of individual and family trajectories. An extensive array of quantitative data collections are examined to illustrate how they allow to study these different aspects of the temporality of exchanges.
\end{abstract}

Key Words: Family solidarity, temporal framework, family trajectories 
Marianne Kempeneers, Éva Lelièvre and Catherine Bonvalet

\section{Résumé}

Le sujet des solidarités familiales intergénérationnelle suscite un intérêt sans précédant tant chez les intervenants que dans le milieu de la recherche et a été le sujet de nombreuses enquêtes centrées sur les liens qui unissent les générations et la dynamique des solidarités familiales au fil du temps. La notion de temps est donc centrale à ce sujet de recherche. Dans cette étude, après un exposé général sur les différentes perspectives longitudinales qui sont utilisées dans les enquêtes de solidarité familiale, nous identifions les principaux problèmes méthodologiques soulevés par la dynamique de ces «solidarités familiales». Trois aspects temporels distincts doivent être considérés : le temps historique, qui s'applique au maintien des solidarités au fil du temps et en dépit des changements structurels de la famille et de la société; le temps générationnel, qui s'applique à la primauté des échanges intergénérationnels; et finalement, le temps biographique qui représente le calendrier des trajectoires de vies individuelles et familiales. Des données variées ont été examinées pour illustrer comment ces méthodes permettent d'étudier les différents aspects de la temporalité des échanges familiaux.

Mots clés : Solidarités familiales, cadre temporel, trajectoires des familles

\section{Introduction}

Since the 1980's, the topic of intergenerational family solidarity has been the focus of unprecedented interest among researchers, in the public arena and among family support services. In Europe in particular, this topic has become a real social issue, as attested by the numerous studies centred on the bonds that unite generations and the dynamics of family solidarity through time. The notion of time is thus central to this field of research and inevitably involves demographics. This is why we propose here to identify the major methodological challenges raised by the concept of "family solidarity" in $21^{\text {st }}$ century demography. To do so, we will start by enumerating the various longitudinal perspectives observed in family solidarity surveys; we will then identify the context of temporal solidarity defined by each approach and we will offer methodological avenues that seem to hold promise for the future. 
The Contribution of a Longitudinal Approach to Family Solidarity Surveys:

Reflections on the Temporality of Exchanges

\section{Overview of Family Solidarities: State of the Art in Research}

As far back as the 1960s and 1970s, anthropologists and sociologists who studied the relational and support networks of their contemporaries stressed the importance of the bonds and exchanges among kin or extended families in an industrial society. It is not by chance that the first important writings on the topic appeared in Western Europe, where population ageing is more acute than in North America (Young and Willmott, 1957; Allan, 1978; Pitrou, 1978; Roussel and Bourguignon, 1976). In the United States and in Canada, a few researchers approached the question very early on (Litwak, 1965; Adams, 1968), but most studies date from the early 1990s (Fortin, 1987, Wellman, 1990; Bengston, 1991; Dandurand and Ouellette, 1992; Godbout and Charbonneau, 1996). In Europe, several important surveys revealed the bonds that unite generations (Bonvalet et al, 1999; Attias-Donfut et al, 1995; Attias-Donfut, 2000) even if the relationships maintained by adult children with their parents are very diverse, and sometimes even ambivalent or conflictual (Finch and Mason, 1993). Moreover, researchers in many countries have been working in collaboration to compare the dynamics of solidarity in these countries in order to better harmonize social welfare policies across the European continent (Ogg and Bonvalet, 2004). What has emerged from all these studies? Five major findings:

a) Family solidarity is maintained over time despite the ever-growing shift toward nuclear families and individualization in our society. Only the modalities vary: contact modalities (frequency and circumstances) and the exchange of goods and services (lending of money, babysitting, provision of accommodation, home care and support, emotional support and care for sick, old or disabled persons). These contact and exchange modalities vary according to residential and affective proximity. They also vary according to gender (women are more active), generation (the "pivotal" or "sandwich" generation is more heavily solicited), and social status (in low-income households, familial support may be preferred over public services due to economic constraints).

b) This solidarity is increasingly expressed on a vertical axis, which means that more contacts and exchanges are observed between generations (parents/children/ grandchildren) than between collateral relatives (brothers/sisters). 
Marianne Kempeneers, Éva Lelièvre and Catherine Bonvalet

c) The family tie presents definite specificities, creating a situation whereby the services exchanged among kin noticeably differ from the forms of support provided by public services, especially in terms of availability, diversity, permanence and cost (Pitrou, 1987; Dechaux, 1996). Furthermore, it has been observed that this bond leads to a kind of flexible reciprocity, often deferred in time and functioning as a sort of "insurance scheme" over the long-term but quite vague and with no guaranties (Coenen-Huther et al, 1994; Godbout and Charbonneau, 1996; Déchaux, 1996). Gift and counter-gift relationships bind individuals to one another, as opposed to mercantile relationships where the exchange ends as soon as one party repays its debt. "Within families, debts are not repaid once and for all, but maintained over years". These kinds of specific reciprocity in familial environments imply that family members must each be simultaneously considered in their role of both donor (or "caregiver") and of donee (or "receiver").

d) Norms of obligation are created and adjusted over time. If we consider a gift as an exchange that serves a relationship, the relationship itself then becomes an arena for creating a sense of obligation, in the sense of "being obligated to". Relationships are thus built in a context of norms based on mutual expectations. Some think that obligation primarily arises in relationships that are established over time, the product of the interactions more than the result of external and imposed norms. For others, this normative system built up within familial and intergenerational relationships over the life course is reinforced by historically and socially constructed norms. This said, the independence norms are also very widespread, and familial support operates more as a "safety net" than as a systematic resource.

e) Family solidarity is more intensely mobilized during critical events in the life course: events such as births, conjugal breakdown, unemployment, illness, loss of independence in old age are all likely to mobilize support from the family circle.

The concept of "family solidarity" that emerges from these findings brings in a notion of time, as well as a concept of exchange (of goods and/or services), both of which are associated with the awareness of a shared sense of belonging that creates bonds of reciprocity and norms of obligation. Three distinct temporal aspects should be considered: historical time, which applies to the maintenance of solidarity over time despite structural change in both families and society; generational time implied by the primacy of "vertical" exchanges (intergenerational); and finally, biographical time, which refers to the calendar of individual and family trajectories, to the critical stages that require the 
The Contribution of a Longitudinal Approach to Family Solidarity Surveys:

Reflections on the Temporality of Exchanges

mobilization of family solidarity and to the alternating caregiver and receiver roles played by family members. It is the interaction of these three temporal aspects that constantly creates and recreates the social landscapes where family solidarity is played out, in ways which vary according to the configuration of family models and to the alternatives offered by work environments or neighbourhoods and by the public authorities at different times in history.

\section{Available Methods for Observing Temporalities}

The following empirical observation methods can be used to collect temporal data:

a) Cross-sectional observation: a situation is observed in its most complex modalities at a specific moment or at key moment(s). Cross-sectional observation offers insights into historical evolution by comparing observations collected at different times and, to a certain point, into intergenerational temporality when the interactive roles of several generations are described.

b) Longitudinal observation: this may be conducted individually or by cohort, retrospectively or prospectively.

- Life event history data is often collected from subjects in a retrospective manner (like the life stories recorded in qualitative studies). In the field of family solidarity surveys, combining data on different aspects of the life course, this type of observation is most often qualified as biographical. It offers insights into the evolution of solidarity over the course of biographical time.

- In the case of panel follow-ups, prospective longitudinal observation is rarely individual. It provides a good method for studying historical evolution by comparing observations made during successive periods on the same sample. As the sample ages, the generational support cycle can be observed, with individuals moving from the role of the child to that of the parent, etc... 
Marianne Kempeneers, Éva Lelièvre and Catherine Bonvalet

\section{Why Time must be brought into the Question}

What are the preferred observation modes in the different family solidarity surveys?

\section{Cross-sectional observation and the different time patterns of support}

The first studies of family solidarity were primarily cross-sectional, the aim being to establish the scope of the family network and the permanence of kinship relationships (Roussel and Bourguignon, 1976; Gokalp, 1978), and to identify actual exchange practices (Pitrou, 1978).

About ten years later, another cross-sectional survey - the Proches et Parents (local family circle) survey conducted by INED (Bonvalet et al., 1999) - marked an important step in the emergence of the question of time and of the changing patterns of support and needs. This survey had a triple objective: to describe kinship, to understand the network of the local family circle and to analyse the support system. Three kinds of support were identified: daily support at the time of the survey, exceptional support during difficult times in the past and finally, recurring support during the course of adult life (housing or employment). Three temporalities are thus explored in the Proches et Parents survey.

\section{Capturing complex temporalities by a complementary qualitative approach}

To complement the Proches et Parents survey, about one hundred semidirective interviews were conducted on family and residential trajectories. The topic of support is included but is not central to the questions and was analysed in a $\mathrm{PhD}$ thesis whose conclusions shed light on the need to see support as a process: "Detailed data analysis has enabled us to make an in-depth study of support that emphasises the broad scope of solidarity established between individuals and their local family circle. We observe that in contemporary families, it is rare to find someone who has neither given nor received support. Support is the norm of kin relationships. However, this investment is not unilateral, since in practically all families it is based on mutual exchange: each individual both gives and receives. Furthermore, the acts of support are not 
The Contribution of a Longitudinal Approach to Family Solidarity Surveys:

Reflections on the Temporality of Exchanges

isolated events or actions: they are part of a process that unfolds over the life course (Ortalda, 2001).

These qualitative interviews demonstrated how the longitudinal approach can contribute to the analysis of these support networks and confirmed that the support network evolves over the life course. In early life, individuals receive from their parents. In the next stage, support is exchanged primarily between members of the same generation, and later on, support is essentially directed at one's children while support to friends, brothers or sisters is reduced. In fact, siblings are clearly more often in competition with the respondent's children than with his/her friends.

\section{A fuzzy temporality}

Though respondents readily describe the support they have either received or given, in the Proches et Parents survey, they do not explicitly mention the temporality of the exchanges. But this vagueness is central: by not specifying the time when support was given or provided, these men and women thus ensure that the resources of their networks remain accessible to them at any time. They deliberately place themselves in a state of "ambiguity", support being a potential relationship that unfolds over time. The analysis of the interviews confirms that acts of support, far from being perceived as specific moments in one's life, are accumulated and reactivated along the life course. The existence of support then becomes the product of a bond established over time, and addressing varied needs.

\section{Cross-sectional exploration of the intergenerational component}

Another way of capturing the longitudinal dimension of support is to survey three generations at the same time, such as in the Trois Générations (three generations) Survey of the CNAV (Attias-Donfut, 1992). This survey focuses on the dimension of filiation and genealogy rather than on that of the conjugal or residential family unit. It takes into account the importance of the generational lineage, accentuated by the increased mean length of life, and the advent of the multigenerational family. In this field of research, this survey is unique not only because it samples three adult generations of the same family by asking identical, symmetrical or complementary questions to each interviewed member, but also because of the generational structure, anchored in the pivotal generation, whose key role was thus highlighted for the first time. 
Marianne Kempeneers, Éva Lelièvre and Catherine Bonvalet

Setting up large panels: prospective longitudinal analysis of behaviours in a sample of households

Yet another way to capture the temporal dimension of support without asking retrospective questions or interviewing different generations of the same families is to create a panel comprising several modules; some of which are carried forward from year to year while others vary from one year to the next. This solution has been chosen by the United-States since 1992 with the Health and Retirement Study (HRS) which concerns only the elderly, by northern Europe countries such as Norway, Belgium, Netherlands and England (with $E L S A)$. However, in some instances, questions relating to support networks sometimes involved only one module on any given year, such as in Luxembourg. In Norway, the first wave started in 2002 (the first results have just been issued). The panel that gives some hindsight is that of Belgium, which took place over 10 years form 1992 to 2002.

With regard to panels, international surveys are in the process of replacing national surveys. One such example is the CGS Generations and Gender Survey, the first wave of which took place in 2004/2005, with a second one planned for 2007. The SHARE Survey of Health Ageing and Retirement in Europe is another.

\section{Combining Relevant Temporalities: The Biographical Approach}

Two recent surveys have broached the topic of family solidarity from an innovative angle: Biographies et Entourage (event histories and contact circle) by INED (2000) and Biographies et solidarités familiales au Québec by the University of Montréal (2004). Both have the following in common:

- They captured the historical importance of lineage combined with changes in the contact circle, beyond the individual life course.

- They examined change in terms of the changing position of individuals over generations: another way to explore the intergenerational component beyond the various time patterns of support.

- And finally, they integrated both qualitative and quantitative approaches. 
The Contribution of a Longitudinal Approach to Family Solidarity Surveys:

Reflections on the Temporality of Exchanges

\section{The Biographies et Entourage survey}

Though the Biographies et Entourage survey was not specifically designed to address the question of family solidarity, the principles of data collection that were used captured many aspects of intergenerational solidarity.

The Biographies et Entourage survey charts the familial, residential and occupational history of 2,830 Ile-de-France inhabitants aged between 50 and 70, and their contact circle. The notion of contact circle in this survey includes not only the family members going back four generations, (blood relatives and relatives by marriage) but also all the people with whom the individual has resided as well as other people, related or not, who have played a key role in the respondents' lives. The concept of contact circle thus extends beyond the strictly intergenerational and familial dimension of the above-mentioned surveys (Lelièvre and Vivier, 2000).

Once this framework of individual interactions defined, the objective of the Biographies et Entourage survey was to follow changes in the respondents' contact circle over their life courses by reconstituting its composition, its geographic distribution and the level of co-residency between its members. It was thus possible to reconstruct the composition of the network in terms of generations, territorial boundaries and its evolution over time; the great majority of people interviewed having each been a child, a grandchild, a parent and then a grandparent in turn.

Though the Biographies et Entourage survey did not collect data on the various kinds of support exchanged among the contact circle during the respondents' life course, indicators can nevertheless be established on the basis of frequency of contacts, geographical distance and affective closeness. It was thus possible to analyse the local or semi-co-resident function of the parent-child relationships (Bonvalet and Lelièvre, 2005a), family territories (Bonvalet and Lelièvre, 2005b) and the cross-solidarity between respondents aged 50 to 60 and their children and surviving parents (Bonvalet and Lelièvre, 2005c).

Finally, the Biographies et Entourage survey offers a way of combining quantitative and qualitative approaches in one data collection process. Efforts were thus particularly focused on devising a questionnaire that encourages a conversation more similar to an open interview than the usual question-andanswer routine of quantitative surveys, but that still calibrates this dialog in a closed questionnaire. Listening to the respondents' interviews provided confirmation of this narrative tone. This represents an intermediate method between a purely objectifying approach aiming to chart life courses independently of the meaning given to them by respondents and, at the other 
Marianne Kempeneers, Éva Lelièvre and Catherine Bonvalet

extreme, the approaches that focus on individuals' own interpretation of their lives (Coninck and Godard, 1989). Though we often, wrongly, associate objective data with quantitative data collection and subjective data with qualitative data collection, Daniel Bertaux (1997) reminds us of the declarative character of the answers in both cases and points out their limitations, a fact confirmed by the results presented here.

\section{The Biographies et solidarités familiales au Québec survey}

The Biographies et solidarités familiales au Québec survey, closely based on the principles of the Biographies et Entourage survey, goes one step further, comparing, over time and three generations, a similar life period with multiple opportunities for family solidarity (birth and early childhood). Large quantities of data were collected on the kinds of support and exchanges identified during that period. Though less systematically, other critical moments were also investigated from the perspective of family solidarity opportunities such as the loss of independence of ageing parents, periods of occupational uncertainty and other periods identified by the respondents as "difficult moments" in their lives (Kempeneers and Vanbremeersch, 2002; Kempeneers et al., 2005a, 2005b, 2006).

The objective of this survey, conducted in the island of Montréal in the summer of 2004, was to analyse the changes in family solidarity in Quebec over three generations, in relation to the transformations in the family, in employment and in public policies. Thanks to the pioneering data collection methodology borrowed from the Biographies et Entourage survey (multidimensional event history questionnaire), Biographies et solidarités familiales au Québec reconstructs the familial, occupational and residential life courses of 500 individuals born in Quebec between 1934 and 1954, along with those of their parents and their children. Three temporal dimensions are mobilized here: biographical, intergenerational and historical.

The approach chosen in the Biographies et solidarités familiales au Québec survey makes it possible to:

- Reconstruct the most important bonds woven over the respondent's life course

- Distinguish between family bonds and "close" bonds (friends, neighbours) and hence examine the specificity of the family bond in relation to support

- Position the entire process along the historical timeline of changes in the family, employment and public support policies. 
The Contribution of a Longitudinal Approach to Family Solidarity Surveys:

Reflections on the Temporality of Exchanges

\section{$21^{\text {st }}$ Century Challenges for Demographers in the Field of Family Solidarity}

This overview of the various ways of collecting temporal data on exchanges among family members pinpoints three major challenges for the demographers of tomorrow: a) to promote experimental research in the field of quantitative data collection; b) to develop collaboration with researchers who favour qualitative methods; c) to pursue avenues for multi-disciplinary dialog.

Quantitative data collection is a very particular field of experimentation. In some way and paradoxically, demographers are the victims of the costs incurred by quantitative data collection methods because they are the privileged analysers of public statistics (which are not experimental) yet at the same time, due to financial constraints, they are rarely the designers of quantitative data collection methods. Note, however, that this is not the case in countries with inadequate public statistics (developing countries), which would indicate that research conducted in the South is worthy of special attention. Moreover, demographers are often associated with public data collection, but the constraints are such and the framework so rigid that research on quantitative data collection tools must be conducted elsewhere. Nevertheless, it is thanks to this partnership that the science of public statistics evolves.

It is also necessary to develop a more active collaboration with researchers who favour qualitative methods, not only by undertaking qualitative follow-up after quantitative surveys (and not everybody does so) but by also integrating qualitative approaches in the entire development process of the quantitative method and in the questionnaires themselves (Lelièvre and Vivier, 2001).

And finally, it is of primordial importance to pursue avenues for pluridisciplinary dialog on the theme of family solidarity, since it is thanks to long years of research conducted in anthropology, history and sociology that our understanding of the dynamics of intergenerational exchanges has been enhanced. The demographic approach to these phenomena is, after all, relatively recent and, faithful to the legacy of anthropology, it has always assumed a dual quantitative/qualitative identity. These disciplinary affinities must be cultivated at all costs in the future. 
Marianne Kempeneers, Éva Lelièvre and Catherine Bonvalet

\section{Acknowledgement:}

Paper presented at the Conference of the Federation of Canadian Demographers on Longitudinal Studies and Demographic Challenges of the 21st Century Université de Montréal, 18-19 November 2005

\section{References:}

Adams, B. N. (1968). Kinship in an urban setting. Chicago, Markham.

Allan, Graham (1978). Sociology of Friendship and Kinship. London, Allen and Unwin.

Attias-Donfut, Claudine (2000). « Rapports de générations. Transferts intrafamiliaux et dynamique macro-sociale ». Revue Française de Sociologie, 41(4) : 643-684.

Attias-Donfut, Claudine (dir) (1995). Les solidarités entre générations. Vieillesse, famille, États. Paris, Nathan.

Bengtson, Vern L. and Robert E. L. Roberts (1991). "Intergenerational Solidarity in Aging Families : An Example of Formal Theory Construction”. Journal of marriage and the family. 53(4) : 856-870.

Bertaux, Daniel (1997). Les récits de vie. Perspectives ethnosociologiques, Collection Sociologie 128, Paris, Nathan

Blöss, Thierry (1997). Les liens de famille. Sociologie des rapports entre générations, Paris, PUF.

Bonvalet, Catherine, Anne Gotman et Yves Grafmeyer (1999). La famille et ses proches. L'aménagement des territoires, Paries, Ined/Puf

Bonvalet, Catherine et Lelièvre, Éva (2005a). Le fonctionnement local des relations parents enfants. Communication au $25^{\text {ème }}$ colloque de l'International Union for the Scientific Study of Population, Tours, France.

Bonvalet, Catherine et Lelievre Éva, (2005b). «Les lieux de la famille», Espaces et Sociétés, La famille dans tous ses espaces, $\mathrm{n}^{\circ} 1-2 / 2005$, pp 99 122. 
The Contribution of a Longitudinal Approach to Family Solidarity Surveys:

Reflections on the Temporality of Exchanges

BonvaleT, Catherine et Lelièvre, Éva (2005c). « Relations familiales des personnes âgées », Retraite et Société, Les nouvelles données démographiques, $\mathrm{n}^{\circ} 45$, juin 2005, pp 44-69.

Bonvalet, Catherine et Ogg, Jim (2006), «Enquêtes sur l'entraide familiale en Europe ». Paris, Ined, Méthodes et Savoirs n ${ }^{\circ} 4$.

Coenen-Huther Jacques, Jean Kellerhals et Malik Von Allmen (1994), Les réseaux de solidarité dans la famille, Lausanne, Éditions Réalités sociales.

Dandurand, Renée B. et Françoise-Romaine Ouellette (1992). «Travail des mères, garde des enfants et soutien de l'entourage dans trois quartiers montréalais», dans Dandurand, Renée B. et Françoise Descarries (dir.) Mères et travailleuses. De l'exception à la règle, Québec, IQRSC, pp. 129-162.

Déchaux, J-H. (1996), «Les services dans la parenté : fonctions, régulation, effets », dans Kaufmann, Jean-Claude (ed), Faire ou faire-faire ? Familles et services. Rennes, Presses Universitaires de Rennes, pp. 39-54.

De Coninck, F. et F. Godard (1989). 'L'approche biographique à l'épreuve de l'interprétation. Les formes temporelles de la causalité", Revue française de sociologie, 31, pp 23-53

ELSA (English Longitudinal Study on Ageing) http://www.ifs.org.uk/elsa/

Finch, Janet et Jane Mason (1993). Negociating Family Responsability. London/New-York, Tavistock/Routledge.

Fortin, Andrée (1987). Histoires de familles et de réseaux. Montréal, St-Martin.

Godbout, Jacques et Johanne Charbonneau, (1996), La circulation du don dans la parenté. Une roue qui tourne, INRS- urbanisation, Montréal.

Gokalp, Catherine (1978). « Le réseau familial ». Paris, Ined, Population 6.

HRS (Health and Retirement Study) http://hrsonline.isr.umich.edu/

Kempeneers, Marianne et Marie Vanbremeersch (2002). L'Enquête-Pilote «Biographies et entourage » au Québec. Rapport d'activités présenté au Ministère de la famille et de l'enfance au Québec. 
Marianne Kempeneers, Éva Lelièvre and Catherine Bonvalet

Kempeneers, Marianne, Marie Vanbremeersch et Isabelle VAN PEVENAGE (2005a). Pour une approche biographique des solidarités familiales au Québec, Communication présentée au Colloque de l'ACFAS, Mai 2005, Chicoutimi

Kempeneers, Marianne, Marie Vanbremeersch et Isabelle VAN PEVENAGE (2005b). Les solidarités à travers les générations : qui est présent au moment de la naissance des enfants? , Communication présentée au Colloque du CSSS Nord de l'Île et St Laurent « La famille et les relations intergénérationnelles », Mai 2005, Montréal

Kempeneers, Marianne, Marie Vanbremeersch et Isabelle VAN PEVENAGE (2006). Lieux de vie et entourage familial au Québec, Communication présentée au Colloque de l'ACFAS, Mai 2006, Univ. McGill, Montréal

Lelièvre Éva et Géraldine Vivier (2001). «Évaluation d'une collecte à la croisée du quantitatif et du qualitatif, l'enquête " Biographies et entourage " », Population, 56 (6) : 1043-1074.

Litwak, E. (1965). "Extended Kin Relations in an Industrial Democratic Society". In Shanas, A. and G. F. Streib (eds). Social Structure and the Family: Generational Relations. Englewood Cliffs, NJ, Prentice Hall.

Ortalda, Laurent (2001). «Le système d'entraide au sein de la parenté : entre logiques sociales et pratiques familiales. Thèse de Doctorat, Université Paris X, Nanterre.

Ouellette, Françoise-Romaine et Renée B. Dandurand (2000). «L'anthropologie des parentés euro-américaines», Anthropologie et sociétés, 24(3) : 5-20.

Pitrou, Agnès (1978 et 1992). Les solidarités familiales, Toulouse, Privat.

Pitrou, Agnès (1987). « Dépérissement des solidarités familiales ? ». L'année sociologique. 3ème série, 37 : 207-224.

Roussel, Louis et Bourguignon, Odile (1976). « La famille après le mariage des enfants. Étude sur les relations entre générations ». Paris, Ined/Puf. Travaux et Documents n ${ }^{\circ} 78$.

Segalen, Martine (1995). Continuités et discontinuités familiales : approche socio-historique du lien intergénérationnel. In Attias-Donfut, Claudine. Les solidarités entre générations. Vieillesse, famille, États. Paris, Nathan. 
The Contribution of a Longitudinal Approach to Family Solidarity Surveys: Reflections on the Temporality of Exchanges

SHARE (Survey of Health, Ageing and Retirement in Europe):

http://www.share-project.org/index.php?page=Home\&menue $=1 \&$ sub $=$

Wellman, Barry (1999). Networks in the Global Village, Bouder, Westview Press.

Young M., Willmott, P. (1957). Family and Kinship in East London, Londres, Routledge and Kegan Paul. 